\title{
The Environment Factors of Supply Chain Risk Management: A Conceptual Framework
}

\author{
Mohd Faizol Rizal Mohd Rasid ${ }^{1}$, Irwan Ibrahim², Alwi Shabudin3 \\ ${ }^{1}$ Department of Economics and Financial Studies, Faculty of Business and Management, University Technology MARA \\ Cawangan Selangor, Campus Puncak Alam \\ ${ }^{2}$ Department of Technology and Supply Chain Management Studies, Faculty of Business and Management, University \\ Teknologi MARA Cawangan Selangor, Campus Puncak Alam \\ ${ }^{3}$ Malaysia Institute of Transport, MITRANS, University Technology MARA Cawangan Selangor, Campus Shah Alam
}

*Corresponding author: faizolrizal@uitm.edu.my

Received 13 December 2019;

Accepted 21 December 2019;

Published 31 December 2019

\begin{abstract}
The purpose of this study is to examine the influence of environment management practices towards supply chain risk management. This study is conducted to find the relationship between environment variables and relate factors that influence supply chain risk management. The research will explore the dimension environment management practices that are technological, organizational and environmental aspect of environment management towards the supply chain risk management model. The paper theoretically develops logic for that environmental management practices is an important factor towards supply chain risk management in order to remain competitive in the challenging and competitive business environment.
\end{abstract}

Keywords: supply chain risk management, environment management practices, environment and attitudes awareness, technological.

\subsection{INTRODUCTION}

In the beginning of 1990s, studies on supply chain management are focus in the improvement of cost-efficiency (Thun \& Hoenig, 2011). Then companies put more effort on streaming line the supply chain process as a competitive advantage to compete with competitor (Barve \& Muduli, 2011). Next, companies incorporated their operations with just-in-time and just-in-sequence in order to create lean supply chains (Kadarova \& Demecko, 2016). With lean supply chains results in managing low inventories but leads to high vulnerability since turbulences in the supply chain can barely be compensated without safety stocks (Khan, Akhtar, \& Merali, 2018). This vulnerability is one of the sign in increasing supply chain risks. The more complex a network is, the more interfaces do exist and the higher the vulnerability will be (Peck, 2005). Furthermore, the globalization era increases supply chain risks because aspects such as transportation risks, cultural risks or exchange rate risks (Shenoi, Dath, Rajendran, \& Shahabudeen, 2018). Additionally, consequences of supply chain disruptions are financial losses, a negative corporate image or a bad reputation eventually accompanied by a loss in demand as well as damages in security and health. Thus, these risks and their consequences will be result in negative performance of supply chain. Although supply chain risk management has gained much attention, there is a lack of work on the aspect of environmental management in managing supply chain risk (Hazen, Cegielski, \& Hanna, 2011; Ibrahim \& Jaafar, 2016a). There is a need for empirical work in the field of supply chain risk management analyzing the environment management aspect and investigating instruments for an effective environment management practice in manage supply chain risk strategy.

Lately, companies have developed effective supply chain risk management (SCRM) strategies in tackling to the uncertain environments, such as dynamic pricing, product assortments, multi-sourcing strategies, and vendor managed inventory ( $\mathrm{Yu}$, Cadeaux, Luo, Qian, \& Chen, 2018). The comprehensive distribution of operations including suppliers, manufacturing plants, warehouses and customers has increased company network complexity and risk vulnerability (Tsang et al., 2018). This phenomenon has led to increased interest in supply chain risk management (SCRM) to cope with complex supply chain. SCRM has received increased attention from researchers and practitioners because of the uncertainty and complexity facing supply chains (Kumar et al.,2018). SCRM provides effective tools and practices which, aligned with the corporate strategy, mitigates the challenges created by uncertainty and complexity.

Nevertheless, it is important to consider the factors of environmental issues in implementing SCRM strategy because nowadays, the main problem of industries is the issue of environmental pollution (Zhu, Sarkis, \& Lai, 2019). In combating the pollution issues while the company managing their supply chain, the green supply chain (GSC) is one of the effective strategy to implement in an organization. Besides pollution, with the acceleration of the government regulations and rules to achieve 
environmental standards and the increasing demands of consumers to supply green products, companies are moving forward in development in making their supply chain more agile and green to survive in the competition arena (Sayyadi Tooranloo, Alavi, \& Saghafi, 2018).

Environment management practices (EMP), or in other term environment management system (EMS), has captured the interest of many practitioners and scholars in recent. This popularity has been due to the fact that EMP is a vital element environmental protection and awareness. With the increased customer concern for environmental protection and awareness, the demand for more stringent environmental regulation on product life-cycle, product end-of-life and on production processes of organizations has increased (Ibrahim \& Jaafar, 2016a). Hence, a number of environmental laws and regulations have been legislated to hold organizations more accountable for their environmental responsibilities. Therefore, the need for organizations to effectively address environmental issues has increased due to either external reasons, example of government regulations, or, internal reasons example of company's policy (Ibrahim \& Jaafar, 2015). Consequently, many organizations are exploring the possibility of including environmental matters into their operations due to changes in legislation, especially on the health and safety front. However, research shows that many organizations are gradually to adopt this new form of management. The factor of employee's resistance to change has been cited by many researchers as one of the barriers to EMP (Ibrahim \& Jaafar, 2016b).

One of the environment tools that is suits in SCRM strategy in organization is Environment Management Practices (EMP) tools. EMP is a tool for an organization's managing their impacts activities toward the environment that provides a structured approach to plan and implement environment protection measures. An EMP monitors environmental performance; similar to the way a financial management system monitors expenditure and income and enables for an organization to checks regularly company's financial performance (Ibrahim \& Jaafar, 2016a, 2016b). In addition, an EMP integrates environmental management into a company's daily operations, long-term planning and other quality management systems (Chavan, 2005), a tool for an organization use to implement an environmental policy (Ann, Zailani, \& Wahid, 2006), tool for illustrates an extension of the core principles of total quality programs to managing the environment (Florida \& Davidson, 2001) and a systematic application of business management to environmental issues (Shahrin, Abd Rahman, Zainol, Salmi, \& Abdul Wahab, 2019; Suzila, Asmalia, \& Nik, 2016; Florida \& Davidson, 2001).

\subsection{PROBLEM STATEMENT}

This research is focused on environment management practices (EMP) factors that influenced supply chain risk management (SCRM) strategy for the manufacturing industry in Selangor. Generally, manufacturing firms in Malaysia is witnessing a profound increase in the deployment of a range of Environment Management Practices (EMP) for environment sustainability and performance. While assessing the adoption of EMP in environmental performance, a need for understanding the factors that influence manufacturing companies' acceptance of EMP as an environment management tool and to manage their daily SCRM strategy operations and procedures.

Thus, this study attempted to expand the well-established Technology-Organization-Environment Model by adding the crucial factor of environment awareness and attitude as an environment management tools and assess the SCRM strategy in manufacturing firm in Selangor. The research model thus has a) Independent variables - (i) Technology Factors (F) (ii) Organization Factors (OF) and (iii) Environment Factors (EF), along with b) Dependent variables - (iv) Supply Chain Risk Management (SCRM). Theoretically, Technology, Organization and Environment factors is expected to influence adoption behaviour, with (c) mediating variables - environment awareness and attitude at manufacturing firm in Selangor.

The objective of this paper is to propose variables or construct the influence of environment management practices towards supply chain risk management.

\subsection{RESEARCH QUESTION}

There are several questions that have been developed regarding the problems statement occurred as followed:

\subsection{Main Research Question}

3.1.1. What is the factor that will influence environment management practices towards supply chain risk management?

\subsection{Specific Research Questions}

3.2.1Thus technological factors influence the supply chain risk management?

3.2.2 Thus technological factors influence the environmental awareness and attitudes?

3.2.3 Thus organizational factors influence the supply chain risk management?

3.2.4 Thus organizational factors influence the environmental awareness and attitudes?

3.2.5 Thus environmental factors influence the supply chain risk management?

3.2.6 Thus environmental factors influence the environmental awareness and attitudes?

3.2.7 Thus environmental awareness and attitudes could influence the supply chain risk management?

\subsection{RESEARCH OBJECTIVE}

This study also has developed several objectives in order to answer all the research questions. This objective will be as a guide in this study to conduct the research. They are as follows:

\subsection{Main Research Objective}

4.1.1 To identify the relationship between the determinant factor of supply chain risk management.

\subsection{Specific Research Objectives}

4.2.1 To identify the relationship between technological factors with supply chain risk management.

4.2.2 To identify the relationship between technological factors and environment awareness and attitudes.

4.2.3 To identify the relationship between organizational factors with supply chain risk management.

4.2.4 To identify the relationship between organizational factor and environment awareness and attitudes.

4.2.5 To identify the relationship between environmental factor with supply chain risk management.

4.2.6 To identify the relationship between environmental factor and environment awareness and attitudes. 
4.2.7 To identify the relationship between environment awareness and attitudes with supply chain risk management.

\subsection{SIGNIFICANCE OF STUDY}

This research explores influence of environment management practices towards supply chain risk management. Apart from the determinant factors of TOE that are composed of technological, organizational, and environmental dimensions, one construct, the variable of environmental awareness and attitudes resulting in an integrated model for assessing the determining factors of supply chain risk management focusing in environmental aspect.

Firstly, this study is significant to individual which are related to the issues in environment in a company, particularly responsiveness. At the very least, these individuals can enhance their knowledge on the factors that influence the environment management practices towards supply chain risk management.

In any company, environment is one of the important aspects that need to be focus on rather than aim for the higher sales and profit it. In fact, managers play an important role to ensure all the employees follow the rules and regulation regarding safety, health and environment matter. In addition, all parties in the company need to be together as one and always bear in their mind on how important for them to ensure every place in the company was clean and good condition. Other than that, this study is important to the management since they will understand more about the environment management practices factors that will influence supply chain man risk management

\subsection{SCOPE OF STUDY}

The scope of this study will mostly revolve on environment management practices towards supply chain risk management. Variables related to this subject matter of studies have been identified. Technology Factor, Organization Factor and Environment Factor are the independent variables. Environmental awareness and attitudes is a mediating factor while supply chain risk management as the dependent variable. The research methodology for this research is going to be a set of questionnaire and also will be generated from an extensive literature review on this particular subject.

\subsection{LITERATURE REVIEW}

\subsection{Environment Management Practices (EMP)}

An EMP or EMS is a tool for an organization's managing their impacts activities toward the environment. It provides a structured approach to plan and implement environment protection measures. An EMP monitors environmental performance; similar to the way a financial management system monitors expenditure and income and enables for an organization to checks regularly company's financial performance. An EMP integrates environmental management into a company's daily operations, long-term planning and other quality management systems (Chavan, 2005).

Environmental management practices (EMP) is one of the most important tools available for the purpose of making the organizations more environmentally proactive and efficient (Emilsson, 2002). Through the establishing of an EMP, the company can demonstrate to clients and the public that they take environmental impacts seriously. In addition, an efficient EMP also can improve company's operation process and brings economic benefits. Nowadays more and more companies have realized the importance of the EMP and engaged in the EMP implementation practice.

\subsection{Technological Factors}

Technological factors have often been taken into account in the literature on technical innovation. However, their influences on environment management practice adoption are scarcely analyzed. Several technological factors have been discussed on their influences on technical innovation, including relative advantage, compatibility, complexity, trialability, observability, ease of use, perceived usefulness, information intensity, and uncertainty (Tornatzky \& Klein, 1982) This research focuses mainly on relative advantage, compatibility, and complexity because these three factors have consistently been found to be more important in influencing adoption behavior of technological innovation than the other factors (Tornatzky \& Klein, 1982).

\subsection{Organizational Factors}

Organizational factors are frequently considered in research on technical innovation and environmental management. A variation of organizational characteristic variables such as quality of human resources, top management's leadership skills, organizational support, organizational culture, and organizational size has been discussed on their influences on technical innovation (Kimberly \& Evanisko,1986) and environmental strategy (Etzion, 2007).

In general, adequate organizational resources and qualified organizational learning capabilities are two relevant organizational characteristics to advance technical innovation as well as environmental performance (Russo \& Fouts,1997) and environment management practices adoption (González, Sarkis, \& Adenso-Díaz, 2008). Thus, this study focuses mainly on the organizational support, quality of human resources, and company size because they are organizational resource-related variables widely analysed in research on technical innovation and environmental management (Ho \& Lin, 2012).

\subsection{Environmental Factors}

The environmental factors in this research refer to the external environment in which a company conducts its business. Several environmental variables such as stakeholder pressure, environmental uncertainty, environmental munificence, governmental support, competition, and network relations have been argued in the literature of technical innovation (Frambach \& Schillewaert, 2002) and environmental management (Etzion, 2007) Variables such as stakeholder pressure, external resource availability, and environmental uncertainty are consistently regarded as primary environmental factors influencing technical innovation (Jeyaraj, Rottman, \& Lacity, 2006) and environmental strategy (Aragón-Correa, Hurtado-Torres, Sharma, \& GarcíaMorales, 2008). The government supports the resources for innovation adoption (Lee, Lee, \& Kwon, 2005). Therefore, this research focuses mainly on the influences of stakeholder pressure, governmental support, and environmental uncertainty.

\subsection{Environmental Awareness and Attitudes}

Numerous findings have focused on consumer attitude and awareness of environment management practices including European countries, USA, and China. These researches are focused on the factor of awareness and attitude. Ibrahim \& Jaafar (2016b) found that individual consumers' positive attitudes towards protecting and improving the environment and their perceptions of fair trade along with local production and availability of actionrelated knowledge have a positive association with consumers' 
green practices on purchases product. Ibrahim \& Jaafar (205) reveals that consumers' positive attitudes towards using green electricity have also been found to be one of the factors to influence their green electricity adoption intention. Plus, (Ho \& Lin, 2012) study suggests those consumers' cultural backgrounds and beliefs, and their ecological knowledge and ecological effect have a significant role in influencing general environmental attitudes. Moreover, Etzion (2007) conclude that environmental plans to influence one's environmental attitudes will be fail unless they are rooted in their respective culture for which 'policy makers need to devise approaches that allow the creation of cultural and social capital' within communities rather than trying to compensate for the loss of economic capital.

Activity such as recycling, waste reduction, energy saving, energy conservation, travel mode choice, travel behaviour, car-use, bus-use, public transportation, cycling, walking, pro-environmental mobility behaviour, water conservation, organic food, green consumerism, green purchases, ethical behaviour, environmentfriendly buying behaviour, environmental consumer behaviour, ecological consumer behaviour, green consumption, green consumer behaviour, ecological behaviour, pro-environmental behaviour, conservationism, environment-friendly behaviour, environment protection behaviour, ecological behaviour and personal norms, ecological behaviour and morality, and proenvironmental attitudes are the sign of environmental behaviour and sustainability practices (Rajesh et al., 2015). Consumer's believes that many environmental problems are the consequences of their daily behaviour and there is now a trend towards consumers preferring to choose greener lifestyle. Neiger et al (2009) show that green practices are influenced by a firm's sustainability orientation and business strategy. Numerous studies have also reported that having an environmental friendly attitude will lead to green behaviors and practices (Ozaki 2011).

Hence, the mediating factors in this framework are environment awareness and attitudes factors. Each of the constructs from the variables represents (Gadenne, Kennedy, \& McKeiver, 2009) Model of External Influences on Environmental Awareness and Practices (MEAP). Based on the Gadenne's MEAP construct; general awareness, cost benefits awareness, and environmental attitudes; these are the characteristic of an individuals to show the level of their concerns and responsiveness towards the environment.

\subsection{Supply Chain Risk Management}

Supply chain risks management (SCRM) may result from manmade (human beings) problems or natural disasters, and can have major consequences for firms, including financial and operational problems which potentially leading to business discontinuity (Craighead et al., 2007; Rajesh et al., 2015). SCRM is aimed at developing strategies for the identification, assessment, treatment, and monitoring of risks in supply chains (Neiger et al., 2009; Tummala and Schoenherr, 2011; Ho et al., 2015). As a process, SCRM has been suggested that risk identification, risk assessment, risk treatment, and risk monitoring represent the four (4) main stages of the SCRM process (Zsidisin et al., 2005; Hachicha and Elmsalmi, 2014). Several definitions highlight the importance of selecting and implementing appropriate SCRM strategies (Faisal et al., 2007; Manuj and Mentzer, 2008b). This is broadly referred to as the pathway to SCRM; and includes external coordination and collaboration among supply chain partners, and the internal implementation of SCRM strategies.

\subsubsection{Objective of Supply Chain Risk Management a. Financial Perspective}

As a financial tool, SCRM involves cash-flow management to ensure profitability (Faisal et al., 2007) and to save costs (Manuj and Mentzer, 2008b).

\section{b. Business Continuity Perspective}

As a business continuity strategy, SCRM manages exposure to serious business disruptions arising from risk within and outside the supply chain (Yiyi and Mark, 2018). SCRM aims to build the capability to reduce vulnerability and ensure business continuity (Jüttner, 2005; Goh et al., 2007; Wieland and Wallenburg, 2012). When a firm is better able to manage risks than the competition, it can lead to an improved market position. Thus, SCRM aims not only to reduce costs and vulnerability but also to ensure profitability, business continuity, and potentially longer-term growth (Yiyi and Mark, 2018).

\subsubsection{A New Definition of Supply Chain Risk Management}

The identification, assessment, treatment, and monitoring of supply chain risks, with the aid of the internal implementation of tools, techniques and strategies and of external coordination and collaboration with supply chain members so as to reduce vulnerability and ensure continuity coupled with profitability, leading to competitive advantage.

\subsection{RESEARCH FRAMEWORK}

Theoretical framework considered as a conceptual model of how researchers theorize or make logical sense of the relationship between the several factors that have been identified. It flows logically from previous research that related to the subject. In this case, the article from (Ibrahim \& Jaafar, 2015) help this study to identified the research framework. It explains over the interrelationship among the variables that are said to be important to the dynamics of the situation being studied. The conceptual framework assumes the hypotheses and tests certain relationship between variables and therefore improves our understanding on the problem being studied.

In spite of this, there are components of the theoretical framework that needs to be look upon. The variable pertinent to the study should be clearly recognized and labelled. Furthermore, the discussions should focus on the interrelationships among two or more variables and how they can affect the dependent variable. If the nature and direction of relationship can be predetermined based on previous research, some indications should be given whether the relationship would be positive or else. Finally, a schematic diagram of the theoretical framework should be given so that people can easily conceptualize the theorized relationship. Since theoretical framework is basically used to identify the network of relationship between variable, we need to understand the variables that is being used in this study.

\subsection{THEORETICAL FRAMEWORK}




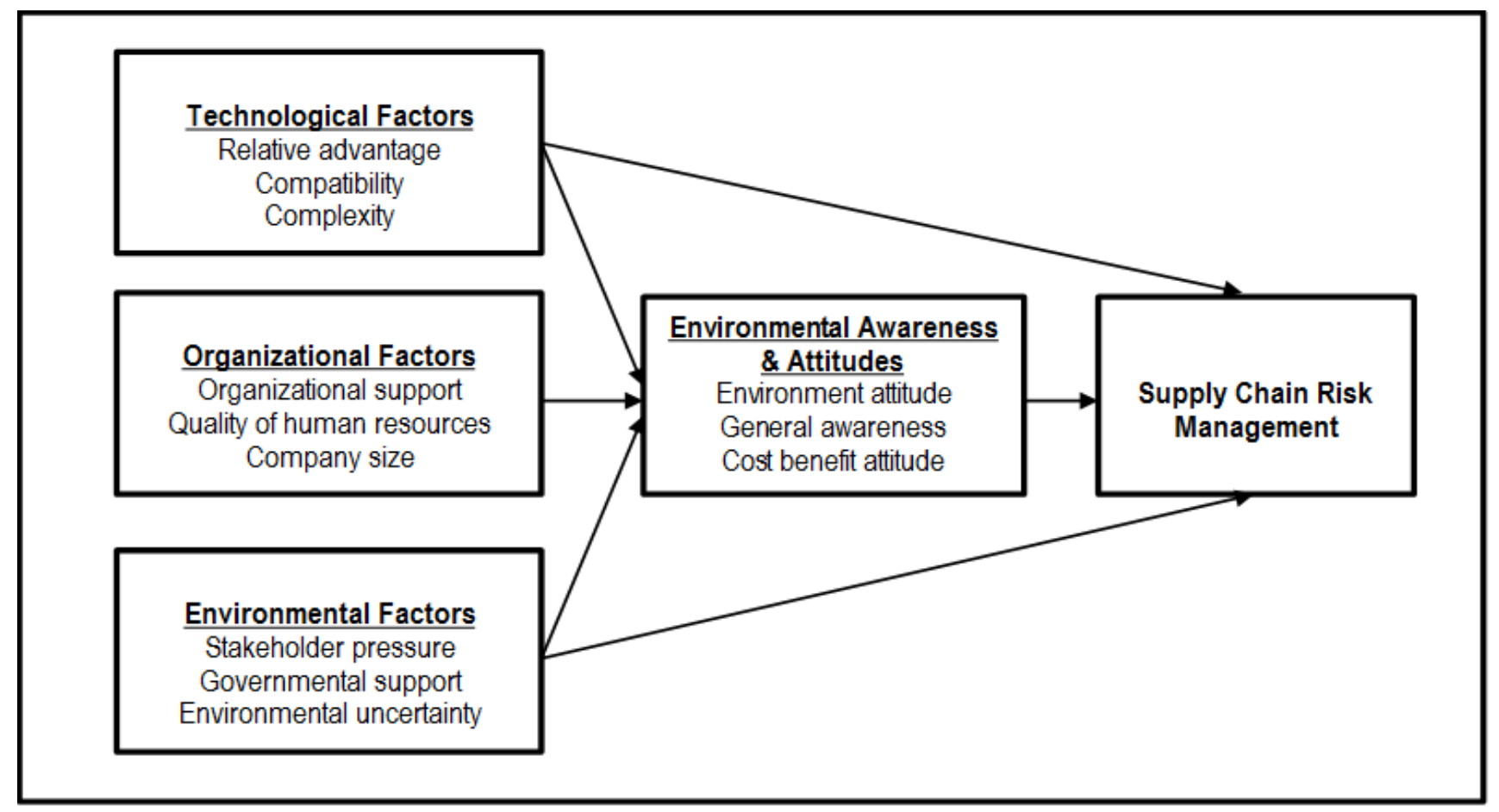

Figure 1: Theoretical Framework

This conceptual framework is adopted from the article of (Ibrahim \& Jaafar, 2015) because of first, the variables is easy to understand and straightforward. Researchers argue on environment management practices adoption, there are many articles that related to one another. People may be confused due to many terms, definitions and features on a topic that they want to focus on. This variable however, is easy to understand and to adopt and to the people correspondent to this study itself. It is simple and convenient to those who wish to learn on the subject matters.

Secondly, it is not intricate to interpret. This is somehow related to the first point that is easy to understand. For people to interpret, one must understand the subject they are studying for. Then they can easily interpret the meaning of it. Furthermore, because the variables are easy and straightforward to understand, so the subject is easy to interpret to another person because of the better understanding of the study.

\subsection{SUMMARIZATION}

To summarize this research, this paper has been enclosed with the problem statement, dependent variable and independent variable to help in determine the research objective and research question. The independent variables are used to help in determine supply chain risk management strategy. This research also shows briefly on the influence of supply chain risk strategy. The influences that have been enclosed are technological factor, organizational factor, environmental factor and environmental awareness and attitudes.

\section{REFERENCES}

[1] Ann, G. E., Zailani, S., \& Wahid, N. A. (2006). A study on the impact of environmental management system (EMS) certification towards firms' performance in Malaysia. Management of Environmental Quality: An International Journal, 17(1), 73-93. https://doi.org/10.1108/14777830610639459.

[2] Aragón-Correa, J. A., Hurtado-Torres, N., Sharma, S., \& García-Morales, V. J. (2008). Environmental strategy and performance in small firms: A resource-based perspective. Journal of Environmental Management, 86(1), 88-103. https://doi.org/10.1016/j.jenvman.2006.11.022.

[3] Barve, A., \& Muduli, K. (2011). Challenges to Environmental Management Practices in Indian Mining Industries, 14, 297 301.

[4] Chavan, M. (2005). An appraisal of environment management systems: A competitive advantage for small businesses. Management of Environmental Quality: An International Journal, 16(5), 444-463. https://doi.org/10.1108/14777830510614321.

[5] Craighead, C.W., Blackhurst, J., Rungtusanatham, M.J. \& Handfield, R.B., (2007), "The severity of supply chain disruptions: Design characteristics and mitigation capabilities”, Decision Sciences, Vol. 38 No. 1, pp. 131-156.

[6] Etzion, D. (2007). Research on Organizations and the Natural Environment, 1992-Present: A Review. Journal of Management, 33(4), 637-664. https://doi.org/10.1177/0149206307302553.

[7] Faisal, M.N., Banwet, D.K. \& Shankar, R., (2007), "Management of Risk in Supply Chains: SCOR Approach and Analytic Network Process", Supply Chain Forum: An International Journal, Vol. 8 No. 2, pp. 6679.

[8] Florida, R., \& Davidson, D. (2001). Gaining from green management: Environmental management systems inside and outside the factory.

[9] Frambach, R. T., \& Schillewaert, N. (2002). Organizational innovation adoption: A multi-level framework of determinants and opportunities for future research. Journal of Business Research, 55(2), 163-176. https://doi.org/10.1016/S01482963(00)00152-1.

[10] Gadenne, D. L., Kennedy, J., \& McKeiver, C. (2009). An empirical study of environmental awareness and practices in SMEs. Journal of Business Ethics, 84(1), 45-63. https://doi.org/10.1007/s10551-008-9672-9.

[11] González, P., Sarkis, J., \& Adenso-Díaz, B. (2008). Environmental management system certification and its influence on corporate practices: Evidence from the 
automotive industry. International Journal of Operations \& Production Management, 28(11), 1021-1041. https://doi.org/10.1108/01443570810910179.

[12] Hachicha, W. \& Elmsalmi, M., (2014), “An integrated approach based-structural modeling for risk prioritization in supply network management", Journal of Risk Research, Vol. 17 No. 10, pp. 13011324.

[13] Hazen, B. T., Cegielski, C., \& Hanna, J. B. (2011). Diffusion of green supply chain management. The International Journal of Logistics Management, 22(3), 373-389. https://doi.org/10.1108/09574091111181372.

[14] Ho, Y., \& Lin, C. (2012). An Empirical Study on Taiwanese Logistics Companies' Attitudes Toward Environmental Management Practices. Advances in Management \& Applied Economics, 2(4), 223-241.

[15] Ho, W., Zheng, T., Yildiz, H. \& Talluri, S., (2015), "Supply chain risk management: a literature review", International Journal of Production Research, Vol. 53 No. 16, pp. 50315069 .

[16] Ibrahim, I. bin, \& Jaafar, H. S. binti. (2016a). Factors of Environment Management Practices Adoptions. Procedia Social and Behavioral Sciences, 224(3), 353-359. https://doi.org/10.1016/j.sbspro.2016.05.387.

[17] Ibrahim, I., \& Jaafar, H. S. (2015). Determinant Factor of Environment Management Practices: A Theoretical Framework. International Review of Management and Business Research, 4(4), 1180-1192. Retrieved from http://search.proquest.com/docview/1754045470?accountid=4 9672.

[18] Ibrahim, I., \& Jaafar, H. S. (2016b). Adopting Environment Management Practices for Environment Sustainabilty: A Proposed Model for Logistics Companies. Asian Business Research, 1(1), 70. https://doi.org/10.20849/abr.v1i1.28.

[19] Jeyaraj, A., Rottman, J. W., \& Lacity, M. C. (2006). A review of the predictors, linkages, and biases in IT innovation adoption research. Journal of Information Technology, 21(1), 1-23. https://doi.org/10.1057/palgrave.jit.2000056.

[20] Jüttner, U., (2005), "Supply chain risk management", International Journal of Logistics Management, Vol. 16 No. 1, pp. 120-141.

[21] Kadarova, J., \& Demecko, M. (2016). New Approaches in Lean Management. Procedia Economics and Finance, 39(November 2015), 11-16. https://doi.org/10.1016/S22125671(16)30234-9.

[22] Khan, M. N., Akhtar, P., \& Merali, Y. (2018). Strategies and effective decision-making against terrorism affecting supply chain risk management and security: A novel combination of triangulated methods. Industrial Management and Data Systems, 118(7), 1528-1546. https://doi.org/10.1108/IMDS09-2017-0449.

[23] Kimberly, J. R., \& Evanisko, M. J. (1986). Organizational innovation: The influence of individual, organizational, and co ... Academy of Management Journal.

[24] Kumar, V., Bak, O., Guo, R., Shaw, S. L., Colicchia, C., Garza-Reyes, J. A., \& Kumari, A. (2018). An empirical analysis of supply and manufacturing risk and business performance: A Chinese manufacturing supply chain perspective. Supply Chain Management, 23(6), 461-479. https://doi.org/10.1108/SCM-10-2017-0319.

[25] Lee, H. Y., Lee, Y. K., \& Kwon, D. (2005). The intention to use computerized reservation systems: The moderating effects of organizational support and supplier incentive. Journal of
Business Research, 58(11 SPEC. ISS.), 1552-1561. https://doi.org/10.1016/j.jbusres.2004.07.008.

[26] Manuj, I. \& Mentzer, J.T., (2008b), "Global supply chain risk management strategies", International Journal of Physical Distribution \& Logistics Management, Vol. 38 No. 3, pp. 192223.

[27] Neiger, D., Rotaru, K. \& Churilov, L., (2009), "Supply chain risk identification with value-focused process engineering", Journal of Operations Management, Vol. 27 No. 2, pp. 154-168.

[28] Rajesh, R., Ravi, V. \& Venkata Rao, R., (2015), "Selection of risk mitigation strategy in electronic supply chains using grey theory and digraph-matrix approaches", International Journal of Production Research, Vol. 53 No. 1, pp. 238-257.

[29] Russo, M. V., \& Fouts, P. A. (1997). A resource-based perspective on corporate environmental performance and profitability. Academy of Management Journal, 40(3), 534.

[30] Sayyadi Tooranloo, H., Alavi, M., \& Saghafi, S. (2018). Evaluating indicators of the agility of the green supply chain. Competitiveness Review, 28(5), 541-563. https://doi.org/10.1108/CR-01-2017-0009.

[31] Shenoi, V. V., Dath, T. N. S., Rajendran, C., \& Shahabudeen, P. (2018). Strategic action grids: a study on supply chain risk management in manufacturing industries in India. Benchmarking, 25(8), 3045-3061. https://doi.org/10.1108/BIJ-11-2017-0321.

[32] Shahrin, N., Abd Rahman, R. A., Zainol, N., Salmi, N. S., \& Abdul Wahab, M. F. (2019). Making It Green: the Food Packaging Perceptions and Practices of Young Consumers. Malaysian Journal of Sustainable Environment, 1(1), 28. https://doi.org/10.24191/myse.v1i1.5557.

[33] Suzila, N. B. L., Asmalia, C. A., \& Nik, A. D. B. N. Z. (2016). The Implementation Of Green Building In Malaysian Construction Industry: Determination Of Key Success Factors. Malaysian Journal Of Sustainable Environment, 1(2), 64-79.

[34] Thun, J. H., \& Hoenig, D. (2011). An empirical analysis of supply chain risk management in the German automotive industry. International Journal of Production Economics, 131(1), 242-249. https://doi.org/10.1016/j.ijpe.2009.10.010.

[35] Tornatzky, L. G., \& Klein, K. J. (1982). Innovation characteristics and innovation adoption-implementation: A meta-analysis of findings. IEEE Transactions on Engineering Management. https://doi.org/10.1109/TEM.1982.6447463.

[36] Tsang, Y. P., Choy, K. L., Wu, C. H., Ho, G. T. S., Lam, C. H. Y., \& Koo, P. S. (2018). An Internet of Things (IoT)-based risk monitoring system for managing cold supply chain risks. Industrial Management and Data Systems, 118(7), 14321462. https://doi.org/10.1108/IMDS-09-2017-0384.

[37] Tummala, R. \& Schoenherr, T., (2011), "Assessing and managing risks using the supply chain risk management process (SCRMP)", Supply Chain Management: An International Journal, Vol. 16 No. 6, pp. 474-483.

[38] Wieland, A. \& Wallenburg, C.M., (2012), "Dealing with supply chain risks Linking risk management practices and strategies to performance", International Journal of Physical Distribution \& Logistics Management, Vol. 42 No. 10, pp. 887-905.

[39] Yiyi Fan, Mark Stevenson, (2018) "A review of supply chain risk management: definition, theory, and research agenda", International Journal of Physical Distribution \& Logistics Management, Vol. 48 Issue: 3, pp.205-230. 
[40] Yu, K., Cadeaux, J., Luo, N., Qian, C., \& Chen, Z. (2018). The role of the consistency between objective and perceived environmental uncertainty in supply chain risk management. Industrial Management and Data Systems, 118(7), 13651387. https://doi.org/10.1108/IMDS-09-2017-0410.

[41] Zhu, Q., Sarkis, J., \& Lai, K. (2019). Choosing the right approach to green your supply chains. Modern Supply Chain
Research and Applications, MSCRA-02-2019-0006. https://doi.org/10.1108/MSCRA-02-2019-0006.

[42] Zsidisin, G.A., Melnyk, S.A. \& Ragatz, G.L., (2005), “An institutional theory perspective of business continuity planning for purchasing and supply management", International Journal of Production Research, Vol. 43 No. 16, pp. 3401-3420. 